\title{
A tale of the monoclonal anti-CD20 antibodies, in tribute to prof. Wacław Szybalski (1921-2020)*
}

\author{
Grzegorz Stasiłojć, Marcin Okrój and Jacek Bigda ${ }^{\square}$ \\ Department of Cell Biology and Immunology, Intercollegiate Faculty of Biotechnology of UG nad MUG, Medical University of Gdańsk, Gdańsk,
} Poland

Technical advances that lead to the era of targeted therapeutics demanded several milestones that were reached in the second half of the previous century. Professor Wacław Szybalski was the first one to perform a stable gene transfer in eukaryotic cells. To do so, he used his own designed system consisting of HPRTdeficient cells and HAT selective medium. Moreover, the first-ever hybridoma cells were also constructed by Wacław Szybalski's team. These spectacular achievements made him not only a forerunner of gene therapy, but also became a foundation for immunotherapy, as hybridoma and their selection by the HPRT-HAT system turned into a crucial technical step during production of monoclonal antibodies (mAbs). Herein, we present a story of anti-CD20 mAbs, one of the most successful lines of anticancer drugs. When looking back into history, the prototypic mAb rituximab was considered the biggest step forward in the therapy of B-cell malignancies. Nowadays, the second and third generations of anti-CD20 mAbs are approved in clinical use and numerous breakthrough studies on immune effector mechanisms were conducted with the aforementioned immunotherapeutics as a model.

Keywords: monoclonal antibodies, immunotherapy, rituximab, CD20 antigen

Received: 01 July, 2021; revised: 05 August, 2021; accepted: 06 August, 2021; available on-line: 31 August, 2021

$\square_{\text {e-mail: jjbigd@gumed.edu.pl }}$

*This paper is dedicated to Professor Wacław Tadeusz Szybalsk on the 100th anniversary of his birth

Abbreviations: $A D C C$, antibody-dependent cellular cytotoxicity; $A L L$, acute lymphoblastic leukemia; B-ALL, B-cell acute lymphoblastic leukemia; B-CLL, B-cell chronic lymphocytic leukemia; B-NHL, B-cell non-Hodgkin lymphoma; CDC, complement-dependent cytotoxicity; CHOP, cyclophosphamide, hydroxydaunorubicin, vincristine/oncovin, and prednisone; HAMA, human anti-mouse antibodies; HAT medium, medium containing hypoxanthine, aminopterin and thymidine; HPRT, Hypoxanthine-guanine phosphoribosyltransferase

\section{INTRODUCTION}

Antibodies are the major players within the humoral immune response. Their robustness stems from their ability to bind a specific epitope that may cause direct effects on the antigen-bearing cells, as well as from the existence of the Fc domain which triggers effector mechanisms of innate immunity, such as the complement activation, phagocytosis, or antibody-dependent cellular cytotoxicity (ADCC) (Winiarska et al., 2011a; Okroj et al., 2013a). Yet, being effective against numerous pathogens, antibodies may be used against malignant cells as long as they express tumor-specific antigens or differ from their non-transformed counterparts by abnormal expression of tumor-associated antigens (Murawski \& Pfreundschuh, 2010). Proper choice of a molecular target for anticancer antibodies impacts the efficacy and safety of immunotherapy. Therefore, one must use antibodies of defined specificity to ensure on-target effects. Monoclonal antibodies fulfill this demand best, as they are produced by a hybridoma derived from a single clone of B cells, which normally undertake allelic exclusion to ensure monospecificity towards a unique epitope. Nowadays, monoclonal antibodies are commonly used for medical, diagnostic, or research purposes (Stasiłojć et al., 2016; Tobinai et al., 2017). However, obtaining them was not trivial fifty years ago, which is underlined by the fact that the Nobel prize in medicine and physiology was awarded in 1984 to Georges J. F. Köhler and César Milstein for "the principle for production of monoclonal antibodies". The undoubted technical advance that led to the production of antibodies of predefined specificity would not have been made unless several other equally important, but less appreciated milestones had been achieved, including those performed by prof. Szybalski and his coworkers.

\section{MILESTONES OF HYBRIDOMA TECHNOLOGY}

The production of non-specific antibodies in hybridoma cells, which are fusions of myeloma cells and normal lymphocytes, was first described in 1973 (Schwaber \& Cohen, 1973). An improved method for the production of specific, monoclonal antibodies was introduced two years later by Köhler and Milstein (Köhler \& Milstein, 1975). Importantly, this Nobel prize-awarded success was preceded by a sequence of discoveries that brought the understanding of immune system organization, and processes leading to antibody production by $\mathrm{B}$ cells, as well as inventions of molecular tools and techniques. The third Nobel prize winner from 1984, prof. Niels Jerne formulated two breakthrough theories: the first one entitled "Natural-Selection Theory of Antibody Formation " published in 1955 (Jerne, 1955), explaining that an organism has an inborn capacity of creating wide diversity of antibodies, but their selection for massive production depends on actual needs, i.e. the antigen that invades and selects the antibody of the best fit. The second theory, from 1971, entitled "The somatic generation of immune recognition", came near to the idea of processes which are nowadays known as a positive selection of thymocytes and affinity maturation (Jerne, 1971; Forsdyke, 1995). The actual hybridoma technology is based on the fusion of a B cell, providing a defined specificity of antibodies, and a tumor cell, providing an unlimited number of cell divisions in continuous in 
vitro culture. This essential concept in monoclonal antibody manufacturing became reliable only after previous research on myeloma cells, a fusion-inducing agent (Sendai virus), and the construction of a system for the selection of cells that underwent hybridization. Other method than natural generation of myeloma cells was first described by Michael Potter in 1962, who discovered that injection of adjuvants containing mineral oil and heat-inactivated bacteria into the peritoneal cavity of $\mathrm{BALB} / \mathrm{c}$ mice resulted in formation of neoplastic cells (Potter \& Boyce, 1962). Later, cell culture conditions for maintenance of myeloma cells were set up in 1970 (Horibata \& Harris, 1970). The technique originally used to perform the fusion of hybridoma partners by using the Sendai virus was made possible by the earlier work of Yoshio Okada, who demonstrated ability to induce a somatic cell fusion by using this virus (Okada \& Tadokoro, 1963). In 1962 prof. Wactaw Syybalski and his wife Elizabeth demonstrated the first-ever successful and stable gene transfer in a eukaryotic cell that restored the missing metabolic enzyme (Szybalska \& Szybalski, 1962; Bigda \& Koszałka, 2013). Besides this achievement, Szybalski provided a tool for selection of transformed cells, i.e. the HAT-HPRT system. HPRT is an enzyme that enables purine synthesis from hypoxanthine when de novo synthesis is blocked. The HAT selective medium is composed of hypoxanthine, thymidine (an alternative source of pyrimidines), and aminopterin - a blocker of the canonical pathway of nucleotide synthesis. Only cells with functional HPRT are able to continue growth in the HAT medium (Bigda \& Koszałka, 2013). The HAT-HPRT system was adopted into the process of monoclonal antibody production, where HPRT-deficient myeloma cells are used as partners for fusion with B cells, and the HAT medium plays a role as a selection factor for hybrids made of two heterotopic cell types.

\section{THE RISE OF IMMUNOTHERAPY FOR LYMPHOPROLIFERATIVE DISEASES}

Since the concept of monoclonal antibody-based immunotherapeutics against tumor cells became popular, numerous patents and trials appeared in the 80's of the previous century. However, only a few of them turned out to be promising, mostly due to obstacles connected to the delivery of the monoclonal antibody to the tumor, poor induction of the host cytotoxic mechanisms, evasion of the immune response by malignant cells, and toxicity/side effects (reviewed in: Grossbard et al., 1992a). Additional emerging problems, some of which were partially unknown in the age of radio- and chemotherapy, involved the suboptimal pharmacokinetic profile, a decoy of antibodies by shed tumor antigens, modulation of target antigen on tumor cells, anti-idiotypic antibodies, or immune response to the immunotherapeutic antibody. Early experimental immunotherapies against acute lymphoblastic leukemia (ALL), B-cell non-Hodgkin lymphoma (B-NHL), B-cell chronic lymphocytic leukemia (B-CLL), and B-cell acute lymphoblastic leukemia (B-ALL), based on mouse monoclonal antibodies failed due to development of human anti-mouse antibodies (HAMA) in patients, enhanced clearance of the antibodies from their circulation or formation of the antigen-antibody complexes that lead to end organ damage (Grossbard et al., 1992a). Conclusions drawn from these failed attempts suggested min- imization of mouse-derived components in candidate antibodies on one hand, and selection of a proper molecular target on the other hand. The molecular target used in the treatment of malignant lymphoproliferation should ideally be absent on the hematopoietic stem and progenitor cells, and ensure no cross-reactivity with normal cells. One such potential target is a surface-anchored antibody that appears on malignant B cells which typically originate from a single transformed cell, and therefore implies monoclonality in the entire tumor population (Levy et al., 1977). This tumor-specific structure, called an idiotype, offers a possibility to raise anti-idiotypic antibodies. Indeed, the early attempts of B cell-specific immunotherapy used an anti-idiotypic approach and few clinical trials showed promising results (Meeker et al., 1985b). However, many attempts failed due to a rapid clearance of antibodies by circulating tumor antigens (Grossbard et al., 1992a) or emergence of idiotype-deficient clones or subpopulations with a changed idiotype (Meeker et al., 1985a). Application of an immunotoxin was another therapeutic attempt that gained attention in the last decades of the 20th century (Pastan \& FitzGerald, 1991). These compounds omitted the problem of poor activation of the host's effector mechanism by unconjugated monoclonal antibodies as the immunotoxins brought their own one, i.e. a covalent antibody-toxin conjugate. Application of ricin, diphtheria toxin and Pseudomonas exotoxin A was practiced in such setup and numerous immunotoxins were tested in clinical trials (Vitetta et al., 1991; Grossbard et al., 1992a; Grossbard et al., 1992b). Apparently, effective delivery of the immunotoxin and their penetration into bulky masses of the tumor cells (e.g. in non-Hodgkin's lymphoma) remained a challenge. Moreover, the toxicity profile and possibility of unwanted side effects due to capillary leakage and damage of endothelial lining became a limiting factor for this class of drugs (Grossbard et al., 1992a).

\section{THE CD20 MOLECULE AND PROTOTYPIC ANTI-CD20 COMPOUNDS}

The CD20 molecule is present on the surface of B cells at most developmental stages, excluding the very first ones and terminally differentiated plasma cells (Winiarska et al., 2011b). Its exact role in the biology of B cells remained elusive, as knockout mice lacking CD20 did not show any major defects (O'Keefe et al., 1998; Uchida et al., 2004). Based on a case report, its role in the development of an immune response to $\mathrm{T}$-independent antigens was postulated (Kuijpers et al., 2010), and other studies suggested its role in calcium signaling (Uchida et al., 2004; Okroj et al., 2013a), but the results of a recent study put this theory in question and propose that it has an influence on actin polymerization, cell movement and response to homeostatic chemokines (Kozlova et al., 2020). Nevertheless, even if CD20 does not fulfill the definition of a tumor-specific antigen, it possesses a number of advantages, such as a high level of expression, relatively low internalization potential, and high persistence on cell membrane (Okroj et al., 2013a). Since being discovered in 1980, it has become probably the best so far described target for therapeutic antibodies (Stashenko et al., 1980; Marshall et al., 2017). The story of therapeutic anti-CD20 antibodies began in 1997 when the Food and Drug Administration approved the first-ever antitumor monoclonal antibody ritux- 
imab, a chimeric mouse-human specimen consisting of a human IgG1 heavy chain and a mouse variable region (Maloney et al., 1997). Rituximab was tested either in a monotherapy or in combination with established chemotherapy regimens, e.g. CHOP (cyclophosphamide, hydroxydaunorubicin, vincristine/oncovin, and prednisone). After completion of a series of clinical trials in the early years of the 21 st century, introduction of rituximab as a frontline drug was named as the biggest step forward in the treatment of B cell lymphomas undertaken in recent fifty years (Murawski $\&$ Pfreundschuh, 2010). Indeed, 10-year follow-up of diffuse large B-cell lymphoma patients treated with CHOP, with or without rituximab, revealed significant differences in progression-free survival $(36.5 \%$ vs. $20 \%$ ) and overall survival (43.5 vs. 27.6\%), respectively (Coiffier et al., 2010). Still promising, but not that spectacular results, were obtained for patients with B-cell leukemias, which are characterized by lower expression of CD20 when compared to lymphoma cells, and a higher level of endogenous complement inhibitors (Okroj et al., 2013b; Marshall et al., 2017). The suboptimal killing of certain types of malignant $B$ cells, as well as the number of patients refractory to rituximab, pushed forward research on next generations of anti-CD20 antibodies and further studies on their effector mechanisms.

\section{NEW ANTIBODIES, NEW KNOWLEDGE}

Despite possessing only two relatively small loops as the only extracellular parts, CD20 became a molecular target for dozens of different monoclonal antibodies that were developed. Intriguingly, antibodies of the same class with partially overlapping epitopes exerted different effector mechanisms. While appealing,

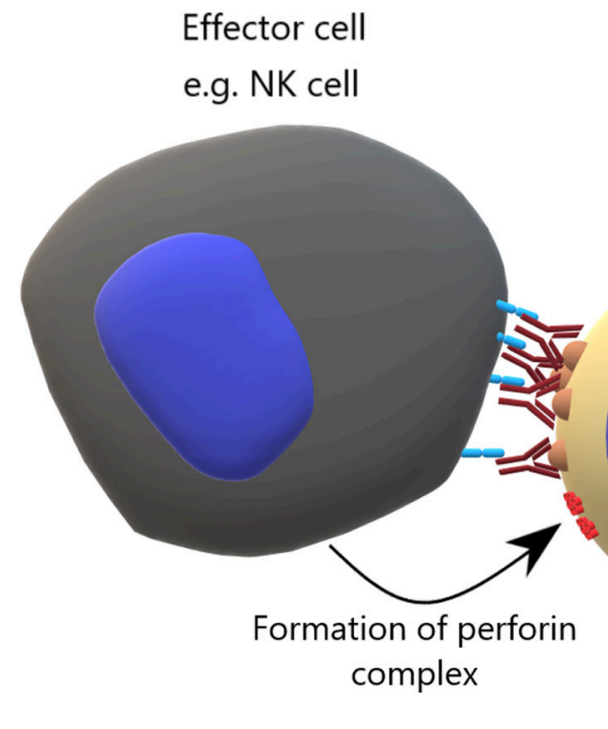

Antibody dependent
cellular cytotoxicity
(ADCC) these novel anti-CD20 specimens served as models for studying the prerequisites necessary for efficient engagement of the host's immune responses, as well as direct effects of CD20 ligation. The cytocidal activity of anticancer antibodies may stem from activation of the host immune effector mechanisms, such as the complement system, mononuclear phagocytes or antibody-dependent cellular cytotoxicity (ADCC) mostly mediated by NK cells (Cragg \& Glennie, 2004; Beers et al., 2008), as illustrated in Fig. 1. Alternatively, antibodies may exert direct effects on signaling pathways leading to induction of programmed cell death (Pedersen et al., 2002; Awasthi et al., 2015). Aggregation of $\mathrm{B}$ cells by antibodies may also lead to reactive oxygen species-induced cell death (Honeychurch et al., 2012).

Engagement of certain effector mechanisms by a given antibody became a basis for classification of the anti-CD20 mAbs as type I and type II specimens (Winiarska et al., 2011b). Type I mAbs are strong activators of the complement system and poor inducers of direct cytocidal effects, in contrast to type II mAbs, which predominantly interfere with cellular signaling cascades. Properties of the antibody, such as the proximity of the binding site to the cell membrane, ability to cluster the target antigen into lipid rafts, off-rate values, and structural features determine the downstream effects (Stasiłojć et al., 2016), and therefore type I/ II classification originally reserved for the anti-CD20 agents can be extended to many other anticancer mAbs. Based on the abovementioned classification, rituximab is an example of type I antibody. The next generation, fully human anti-CD20 antibody, ofatumumab, which was approved for clinical use in 2009 (Marshall et al., 2017), exhibits a more pronounced manifestation of class I characteristics. Similar to rituximab, ofatu-

\section{Formation of membrane attack complex}


mumab contains human IgG1 Fc portion and relocates antigen-antibody complexes into the lipid rafts, but it binds an epitope localized more proximately to the cell membrane (Winiarska et al., 2011b). On the other hand, obinutuzumab, another IgG1-containing specimen, shows type II characteristics and exemplifies the third generation of anti-CD20 antibodies that involves engineering of the Fc part. Obinutuzumab was modified in a way that disables fucose attachment to side polysaccharide chains. Such afucosylated antibody ensures stronger interactions with Fc receptors, thereby enhancing ADCC and antibody-dependent phagocytosis (Freeman \& Sehn, 2018). Moreover, obinutuzumab exerts killing of the target cell by inducing homotypic adhesion and triggering caspase-independent, lysosome-dependent cell death (Alduaij et al., 2011).

The increasing number of either type I or type II antibodies anticipate the question of how to select the optimal therapy for the individual patient and what are the mechanisms of resistance. Effectors of the host innate immunity are robust, but not infinite, and as such prone to exhaustion, as exemplified by either an in vitro model of lymphoma cells challenged by a repeated dose of ofatumumab (Beurskens et al., 2012), or by a clinical observation that patients' response to rituximab was significantly improved when supplemented with fresh-frozen plasma or purified complement components (Kennedy et al., 2004; Klepfish et al., 2009; $\mathrm{Xu}$ et al., 2011). Another reason for resistance to type-I mAbs is endogenous inhibition of the host effector mechanism by tumor cells (Jurianz et al., 1999). Overcoming these evading strategies by excessive application of antibodies is not an optimal solution due to antibody-dependent loss of molecular target by internalization (Beers et al., 2010) or shedding (Dahal et al., 2018). Importantly, selection of the tumor cell population devoid of target antigen and then resistant to therapy can be rescued by application of two different therapeutics which recognize different targets. This attempt was successively demonstrated for the combination of ofatumumab (anti-CD20) and alemtuzumab (anti-CD52) (Baig et al., 2012, 2014), as well as for the anti-CD5 and anti-CD20 specimens (Klitgaard et al., 2013). On the other hand, some of the therapeutics may exhibit antagonistic effects, e.g. inhibitors of SRC kinases and anti-CD20 mAbs, as shown in (Winiarska et al., 2014). Nonetheless, the existence of several therapeutic options is beneficial and offers the possibility to use them in synergistic tandems with better efficacy than each agent administrated alone. Also, type II monoclonal antibodies, such as obinutuzumab which supports a direct cytocidal effect, become more popular as frontline drugs (Tobinai et al., 2017). We (Felberg et al., 2020) and others (Middleton et al., 2015) demonstrated that a number of patients with B-cell malignancies prescribed with type I anti-CD20 antibodies cannot mount efficient complement-dependent cytotoxicity due to primary or secondary deficiencies, and therefore might gain more benefit from application of type II immunotherapeutics. Similarly, a personalized medical attempt should take under consideration the tumor burden and polymorphisms in Fc $\gamma$ receptors as parameters critical for optimal therapeutic schedule and composition (Cartron et al., 2002; Boross et al., 2011; Beurskens et al., 2012).

\section{CONCLUDING REMARKS}

The long tale of therapeutic monoclonal antibodies begun more than 50 years ago not only thanks to the work of Nobel-prize winners Köbler and Milstein, but also many other scientists, including prof. Wactaw $S_{z y-}$ balski, who contributed to making this scientific and medicinal opus real. Through the last decades, we have witnessed a boom in antibody-based anticancer drugs, with anti-CD20 as the first and probably the best-characterized immunotherapeutics. We not only have specimens capable of exerting different effector mechanisms, but we also gained knowledge on how to engineer them to promote certain types of response, which may turn pivotal in personalized medicine. Apparently, this is not the end of progress since new spectacular findings were made recently, with anti-CD20 antibodies as the model. The first Science paper from 2014 has revisited our view on type I/type II antibody's requisites (Diebolder et al., 2014). The authors demonstrated that introduction of mutations into the constant portion of the heavy chain, inducing formation of non-covalent hexamers, can enforce strong complement activation by antibodies that were completely devoid of this feature when unmodified. The second Science publication from 2020 demonstrated the structures of full-length CD20 in complex with rituximab, ofatumumab or obinutuzumab, and explained the details of the antigen-antibody binding that are critical for different downstream effects of these antibodies (Kumar et al., 2020). As this knowledge seems to be adaptable beyond the anti-CD20 antibodies, the abovementioned studies will help to rationally design new immunotherapeutics dedicated to unmet medical needs.

\section{REFERENCES}

Alduaij W, Ivanov A, Honeychurch J, Cheadle EJ, Potluri S, Lim SH, Shimada K, Chan CHT, Tutt A, Beers SA, Glennie MJ, Cragg MS, Illidge TM (2011) Novel type II anti-CD20 monoclonal antibody (GA101) evokes homotypic adhesion and actin-dependent, lysosome-mediated cell death in B-cell malignancies. Blood 117: 4519-4529. https:/ / doi.org/10.1182/blood-2010-07-296913

Awasthi A, Ayello J, Van de Ven C, Elmacken M, Sabulski A, Barth MJ, Czuczman MS, Islam H, Klein C, Cairo MS (2015) Obinutuzumab (GA101) compared to rituximab significantly enhances cell death and antibody-dependent cytotoxicity and improves overall survival against CD20(+) rituximab-sensitive/-resistant Burkitt lymphoma (BL) and precursor B-acute lymphoblastic leukaemia (pre-B-ALL): potential targeted therapy in patients with poor risk CD20 $(+)$ $\mathrm{BL}$ and pre-B-ALL. $\mathrm{Br} J$ Haematol 171: 763-775. https://doi. org/10.1111/bjh.13764

Baig NA, Taylor RP, Lindorfer MA, Church AK, Laplant BR, Pavey ES, Nowakowski GS, Zent CS (2012) Complement dependent cytotoxicity in chronic lymphocytic leukemia: ofatumumab enhances alemtuzumab complement dependent cytotoxicity and reveals cells resistant to activated complement. Leuk. Lymphoma 53: 2218-2227. https://doi.org/10.3109/10428194.2012.681657

Baig NA, Taylor RP, Lindorfer MA, Church AK, LaPlant BR, Pettinger AM, Shanafelt TD, Nowakowski GS, Zent CS (2014) Induced resistance to ofatumumab-mediated cell clearance mechanisms, including complement-dependent cytotoxicity, in chronic lymphocytic leukemia. J Immunol 192: 1620-1629. https:// doi.org/10.4049/jimmunol.1302954

Beers SA, Chan CHT, James S, French RR, Attfield KE, Brennan CM, Ahuja A, Shlomchik MJ, Cragg MS, Glennie MJ (2008) Type II (tositumomab) anti-CD20 monoclonal antibody out performs type I (rituximab-like) reagents in B-cell depletion regardless of complement activation. Blood 112: 4170-4177. https://doi. org/10.1182/blood-2008-04-149161

Beers SA, French RR, Chan HTC, Lim SH, Jarrett TC, Vidal RM, Wijayaweera SS, Dixon SV, Kim H, Cox KL, Kerr JP, Johnston DA, Johnson PWM, Verbeek JS, Glennie MJ, Cragg MS (2010) Antigenic modulation limits the efficacy of anti-CD20 antibodies: implications for antibody selection. Blood 115: 5191-5201. https:// doi.org/10.1182/blood-2010-01-263533 
Beurskens FJ, Lindorfer MA, Farooqui M, Beum PV, Engelberts P, Mackus WJM, Parren PWHI, Wiestner A, Taylor RP (2012) Exhaustion of cytotoxic effector systems may limit monoclonal antibody-based immunotherapy in cancer patients. I Immunol 188: 3532-3541. https://doi.org/10.4049/jimmunol.1103693

Bigda JJ, Koszałka P (2013) Wacław Szybalski's contribution to immunotherapy: HGPRT mutation \& HAT selection as first steps to gene therapy and hybrid techniques in mammalian cells. Gene 525: 158-161. https://doi.org/10.1016/j.gene.2013.03.099

Boross P, Jansen JHM, de Haij S, Beurskens FJ, van der Poel CE, Bevaart L, Nederend M, Golay J, van de Winkel JGJ, Parren PWHI, Leusen JHW (2011) The in vivo mechanism of action of CD20 monoclonal antibodies depends on local tumor burden. Haematologica 96: 1822-1830. https://doi.org/10.3324/haematol.2011.047159

Cartron G, Dacheux L, Salles G, Solal-Celigny P, Bardos P, Colombat $\mathrm{P}$, Watier H (2002) Therapeutic activity of humanized anti-CD20 monoclonal antibody and polymorphism in IgG Fc receptor FcgammaRIIIa gene. Blood 99: 754-758. https://doi.org/10.1182/ blood.v99.3.754

Coiffier B, Thieblemont C, Van Den Neste E, Lepeu G, Plantier I, Castaigne S, Lefort S, Marit G, Macro M, Sebban C, Belhadj K, Bordessoule D, Fermé C, Tilly H (2010) Long-term outcome of patients in the LNH-98.5 trial, the first randomized study comparing rituximab-CHOP to standard CHOP chemotherapy in DLBCL patients: a study by the Groupe d'Etudes des Lymphomes de l'Adulte. Blood 116: 2040-2045. https://doi.org/10.1182/ blood-2010-03-276246

Cragg MS, Glennie MJ (2004) Antibody specificity controls in vivo effector mechanisms of anti-CD20 reagents. Blood 103: 2738-2743. https://doi.org/10.1182/blood-2003-06-2031

Dahal LN, Huang C-Y, Stopforth RJ, Mead A, Chan K, Bowater JX, Taylor MC, Narang P, Chan HTC, Kim JH, Vaughan AT, Forconi F, Beers SA (2018) Shaving is an epiphenomenon of type I and II anti-CD20-mediated phagocytosis, whereas antigenic modulation limits type I monoclonal antibody efficacy. I Immunol 201: 12111221. https://doi.org/10.4049/jimmunol.1701122

Diebolder CA, Beurskens FJ, de Jong RN, Koning RI, Strumane K, Lindorfer MA, Voorhorst M, Ugurlar D, Rosati S, Heck AJR, van de Winkel JGJ, Wilson IA, Koster AJ, Taylor RP, Saphire EO, Burton DR, Schuurman J, Gros P, Parren PWHI (2014) Complement is activated by $\operatorname{IgG}$ hexamers assembled at the cell surface. Science 343: 1260-1263. https://doi.org/10.1126/science.1248943

Felberg A, Taszner M, Urban A, Majeranowski A, Jaskuła K, Jurkiewicz A, Stasiłojć G, Blom AM, Zaucha JM, Okrój M (2020) Monitoring of the complement system status in patients with B-cell malignancies treated with rituximab. Front Immunol 11: 584509. https://doi.org/10.3389/fimmu.2020.584509

Forsdyke DR (1995) Jerne and positive selection. Immunol Today 16: 105. https://doi.org/10.1016/0167-5699(95)80097-2

Freeman CL, Sehn LH (2018) A tale of two antibodies: obinutuzumab versus rituximab. Br J Haematol 182: 29-45. https://doi.org/10.1111/ bjh. 15232

Grossbard ML, Press OW, Appelbaum FR, Bernstein ID, Nadler LM (1992a) Monoclonal antibody-based therapies of leukemia and lymphoma. Blood 80: 863-878

Grossbard ML, Freedman AS, Ritz J, Coral F, Goldmacher VS, Eliseo L, Spector N, Dear K, Lambert JM, Blättler WA (1992b) Serotherapy of B-cell neoplasms with anti-B4-blocked ricin: a phase I trial of daily bolus infusion. Blood 79: 576-585

Honeychurch J, Alduaij W, Azizyan M, Cheadle EJ, Pelicano H, Ivanov A, Huang P, Cragg MS, Illidge TM (2012) Antibodyinduced nonapoptotic cell death in human lymphoma and leukemia cells is mediated through a novel reactive oxygen speciesdependent pathway. Blood 119: 3523-3533. https://doi.org/10.1182/ blood-2011-12-395541

Horibata K, Harris AW (1970) Mouse myelomas and lymphomas in culture. Exp Cell Res 60: 61-77. https://doi.org/10.1016/00144827(70)90489-1

Jerne NK (1955) The natural-selection theory of antibody formation. Proc Natl Acad Sci U S A 41: 849-857. https://doi.org/10.1073/ pnas.41.11.849

Jerne NK (1971) The somatic generation of immune recognition. Eur J Immunol 1: 1-9. https://doi.org/10.1002/eji.1830010102

Jurianz K, Ziegler S, Garcia-Schüler H, Kraus S, Bohana-Kashtan O, Fishelson Z, Kirschfink M (1999) Complement resistance of tumor cells: basal and induced mechanisms. Mol Immunol 36: 929-939. https://doi.org/10.1016/s0161-5890(99)00115-7

Kennedy AD, Beum PV, Solga MD, DiLillo DJ, Lindorfer MA, Hess CE, Densmore JJ, Williams ME, Taylor RP (2004) Rituximab infusion promotes rapid complement depletion and acute CD20 loss in chronic lymphocytic leukemia. J Immunol 172: 3280-3288. https://doi.org/10.4049/jimmunol.172.5.3280

Klepfish A, Gilles L, Ioannis K, Rachmilewitz EA, Eliezer R, Schattner A, Ami S (2009) Enhancing the action of rituximab in chronic lymphocytic leukemia by adding fresh frozen plasma: complement/ rituximab interactions and clinical results in refractory CLL. Ann
N Y Acad Sci 1173: 865-873. https://doi.org/10.1111/j.17496632.2009.04803.x

Klitgaard JL, Koefoed K, Geisler C, Gadeberg OV, Frank DA, Petersen J, Jurlander J, Pedersen MW (2013) Combination of two anti-CD5 monoclonal antibodies synergistically induces complementdependent cytotoxicity of chronic lymphocytic leukaemia cells. $\mathrm{Br} \mathrm{J}$ Haematol 163: 182-193. https://doi.org/10.1111/bjh.12503

Köhler G, Milstein C (1975) Continuous cultures of fused cells secreting antibody of predefined specificity. Nature 256: 495-497. https://doi.org/10.1038/256495a0

Kozlova V, Ledererova A, Ladungova A, Peschelova H, Janovska P, Slusarczyk A, Domagala J, Kopcil P, Vakulova V, Oppelt J, Bryja V, Doubek M, Mayer J, Pospisilova S, Smida M (2020) CD20 is dispensable for B-cell receptor signaling but is required for proper actin polymerization, adhesion and migration of malignant $B$ cells. PLoS One 15: e0229170. https://doi.org/10.1371/journal. pone. 0229170

Kuijpers TW, Bende RJ, Baars PA, Grummels A, Derks IAM, Dolman KM, Beaumont T, Tedder TF, van Noesel CJM, Eldering E, van Lier RAW (2010) CD20 deficiency in humans results in impaired $\mathrm{T}$ cell-independent antibody responses. J Clin Invest 120: 214-222. https://doi.org/10.1172/JCI40231

Kumar A, Planchais C, Fronzes R, Mouquet H, Reyes N (2020) Binding mechanisms of therapeutic antibodies to human CD20. Science 369: 793-799. https://doi.org/10.1126/science.abb8008

Levy R, Warnke R, Dorfman RF, Haimovich J (1977) The monoclonality of human B-cell lymphomas. J Exp Med 145: 1014 1028. https://doi.org/10.1084/jem.145.4.1014

Maloney DG, Grillo-López AJ, White CA, Bodkin D, Schilder RJ, Neidhart JA, Janakiraman N, Foon KA, Liles TM, Dallaire BK, Wey K, Royston I, Davis T, Levy R (1997) IDEC-C2B8 (Rituximab) antiCD20 monoclonal antibody therapy in patients with relapsed lowgrade non-Hodgkin's lymphoma. Blood 90: 2188-2195

Marshall MJE, Stopforth RJ, Cragg MS (2017) Therapeutic Antibodies: What Have We Learnt from Targeting CD20 and Where Are We Going? Front Immunol 8: 1245. https://doi.org/10.3389/fimmu.2017.01245

Meeker T, Lowder J, Cleary ML, Stewart S, Warnke R, Sklar J, Levy R (1985a) Emergence of idiotype variants during treatment of B-cell lymphoma with anti-idiotype antibodies. N Engl J Med 312: 16581665. https://doi.org/10.1056/NEJM198506273122602

Meeker TC, Lowder J, Maloney DG, Miller RA, Thielemans K, Warnke R, Levy R (1985b) A clinical trial of anti-idiotype therapy for B cell malignancy. Blood 65: 1349-1363

Middleton O, Cosimo E, Dobbin E, McCaig AM, Clarke C, Brant AM, Leach MT, Michie AM, Wheadon H (2015) Complement deficiencies limit CD20 monoclonal antibody treatment efficacy in CLL. Leukemia 29: 107-114. https://doi.org/10.1038/leu.2014.146

Murawski N, Pfreundschuh M (2010) New drugs for aggressive Bcell and T-cell lymphomas. Lancet Oncol 11: 1074-1085. https://doi. org/10.1016/S1470-2045(10)70210-2

Okada Y, Tadokoro J (1963) The distribution of cell fusion capacity among several cell strains or cells caused by hvj. Exp Cell Res 32: 417-430. https://doi.org/10.1016/0014-4827(63)90182-4

O'Keefe TL, Williams GT, Davies SL, Neuberger MS (1998) Mice carrying a CD20 gene disruption. Immunogenetics 48: 125-132. https:// doi.org/10.1007/s002510050412

Okroj M, Österborg A, Blom AM (2013a) Effector mechanisms of anti-CD20 monoclonal antibodies in B cell malignancies. Cancer Treat Rev 39: 632-639. https://doi.org/10.1016/j.ctrv.2012.10.008

Okroj M, Eriksson I, Osterborg A, Blom AM (2013b) Killing of CLL and NHL cells by rituximab and ofatumumab under limited availability of complement. Med Oncol 30: 759. https://doi.org/10.1007/ s12032-013-0759-5

Pastan I, FitzGerald D (1991) Recombinant toxins for cancer treatment. Science 254: 1173-1177. https://doi.org/10.1126/science. 1683495

Pedersen IM, Buhl AM, Klausen P, Geisler CH, Jurlander J (2002) The chimeric anti-CD20 antibody rituximab induces apoptosis in B-cell chronic lymphocytic leukemia cells through a p38 mitogen activated protein-kinase-dependent mechanism. Blood 99: 1314-1319. https:// doi.org/10.1182/blood.v99.4.1314

Potter M, Boyce CR (1962) Induction of plasma-cell neoplasms in strain BALB/c mice with mineral oil and mineral oil adjuvants. Nature 193: 1086-1087. https://doi.org/10.1038/1931086a0

Schwaber J, Cohen EP (1973) Human x mouse somatic cell hybrid clone secreting immunoglobulins of both parental types. Nature 244: 444-447. https://doi.org/10.1038/244444a0

Stashenko P, Nadler LM, Hardy R, Schlossman SF (1980) Characterization of a human B lymphocyte-specific antigen. I Immunol 125: 1678-1685

Stasiłojć G, Österborg A, Blom AM, Okrój M (2016) New perspectives on complement mediated immunotherapy. Cancer Treat Rev 45: 6875. https://doi.org/10.1016/j.ctrv.2016.02.009

Szybalska EH, Szybalski W (1962) Genetics of human cell line. IV. DNA-mediated heritable transformation of a biochemical trait. 
Proc Natl Acad Sci U S A 48: 2026-2034. https://doi.org/10.1073/ pnas.48.12.2026

Tobinai K, Klein C, Oya N, Fingerle-Rowson G (2017) A review of obinutuzumab (GA101), a novel type II anti-CD20 monoclonal antibody, for the treatment of patients with B-cell malignancies. $A d v$ Ther 34: 324-356. https://doi.org/10.1007/s12325-016-0451-1

Uchida J, Lee Y, Hasegawa M, Liang Y, Bradney A, Oliver JA, Bowen K, Steeber DA, Haas KM, Poe JC, Tedder TF (2004) Mouse CD20 expression and function. International Immunology 16: 119-129. https://doi.org/10.1093/intimm/dxh009

Vitetta ES, Stone M, Amlot P, Fay J, May R, Till M, Newman J, Clark P, Collins R, Cunningham D (1991) Phase I immunotoxin trial in patients with B-cell lymphoma. Cancer Res 51: 4052-4058.

Winiarska M, Glodkowska-Mrowka E, Bil J, Golab J (2011a) Molecular mechanisms of the antitumor effects of anti-CD20 antibodies. Front Biosci (Landmark Ed) 16: 277-306. https://doi.org/10.2741/3688
Winiarska M, Glodkowska-Mrowka E, Bil J, Golab J (2011b) Molecular mechanisms of the antitumor effects of anti-CD20 antibodies. Front Biosci (Landmark Ed) 16: 277-306. https://doi.org/10.2741/3688

Winiarska M, Bojarczuk K, Pyrzynska B, Bil J, Siernicka M, Dwojak M, Bobrowicz M, Miazek N, Zapala P, Zagozdzon A, Krol M, Syta A, Podszywalow-Bartnicka P, Pilch Z, Dabrowska-Iwanicka A, Juszczynski P, Efremov DG, Slabicki M, Zenz T, Le Roy A et al. (2014) Inhibitors of SRC kinases impair antitumor activity of antiCD20 monoclonal antibodies. MAbs 6: 1300-1313. https://doi. org/10.4161/mabs.32106

Xu W, Miao K-R, Zhu D-X, Fang C, Zhu H-Y, Dong H-J, Wang D-M, Wu Y-J, Qiao C, Li J-Y (2011) Enhancing the action of rituximab by adding fresh frozen plasma for the treatment of fludarabine refractory chronic lymphocytic leukemia. Int J Cancer 128: 2192-2201. https://doi.org/10.1002/ijc.25560 